\title{
Cinnamaldehyde Ameliorates Diet-Induced Obesity in Mice by Inducing Browning of White Adipose Tissue
}

\author{
Jiacheng Zuo Dandan Zhao ${ }^{a} \quad \mathrm{Na} \mathrm{Yu}^{\mathrm{a}}$ Xin Fang ${ }^{\mathrm{b}}$ Qianqian $\mathrm{Mu}^{\mathrm{a}}$ Yue Ma ${ }^{\mathrm{a}}$ \\ Fangfang $\mathrm{Mo}^{\mathrm{a}}$ Rui Wu ${ }^{\mathrm{c}}$ Rufeng Ma ${ }^{\mathrm{a}}$ Lili Wang ${ }^{\mathrm{a}}$ Ruyuan Zhu ${ }^{\mathrm{a}}$ Haixia Liu $^{\mathrm{a}}$ \\ Dongwei Zhang ${ }^{\text {a }}$ Sihua Gao
}

\begin{abstract}
aSchool of Preclinical Medicine, Beijing University of Chinese Medicine, Beijing, ${ }^{b}$ Department of Endocrinology, Beijing University of Chinese Medicine, Third Affiliated Hospital, Beijing, 'Department of Endocrinology, South Area of Guang'anmen Hospital, China Academy of Chinese Medical Sciences, Beijing, PR China
\end{abstract}

\section{Key Words}

Cinnamaldehyde $\bullet$ Anti-obesity $\bullet$ Mice $・$ Fat mass $・$ Adipose tissue browning

\begin{abstract}
Background/Aims: Obesity has become a major health concern with few effective medications. Cinnamaldehyde (CA) has been reported to exhibit anti-diabetic and anti-inflammatory properties. However, whether CA shows anti-obesity activity remains unknown. Therefore, the present study aimed to investigate the potential anti-obesity effects of CA on mice fed a highfat diet (HFD) and to explore the possible mechanisms involved. Methods: Male C57BL/6J mice fed an HFD for 12 weeks were supplemented with CA ( $40 \mathrm{mg} / \mathrm{kg} / \mathrm{day}$ ) via gavage for an additional 8 weeks. Mice fed a standard diet were used as normal controls. Results: The results revealed that $C A$ treatment decreased body weight, fat mass, food intake, and serum lipid, free fatty acid and leptin levels. CA administration also improved insulin sensitivity in HFD-induced obese mice. Additionally, CA inhibited the hypertrophy of adipose tissue and induced browning of white adipose tissue. Uncoupling protein 1 (UCP1) was expressed in white adipose tissue after the oral administration of CA. Furthermore, CA enhanced the expression of the peroxisome proliferator-activated receptor $Y$ (PPAR $\gamma$ ), PR domain-containing 16 (PRDM16) and PPAR $\gamma$ coactivator $1 \alpha$ (PGC-1 $\alpha$ ) proteins in both brown and white adipose tissues. Conclusions: The results suggest that $C A$ exhibits therapeutic potency against obesity by inducing the browning of white adipose tissue in HFD-fed mice.
\end{abstract}

J. Zuo, D. Zhao and N. Yu contributed equally to this work 


\section{Cellular Physiology Cell Physiol Biochem 2017;42:1514-1525 \\ \begin{tabular}{l|l} 
DOI: 10.1159/000479268 & $\begin{array}{l}\text { O 2017 The Author(s). Published by S. Karger AG, Basel } \\
\text { www.karger.com/cpb }\end{array}$
\end{tabular} \\ Zuo et al.: Cinnamaldehyde Ameliorates Obesity}

\section{Introduction}

Obesity is becoming a serious global health concern. The number of obese people has rapidly increased recently due to unhealthy lifestyles, such as overeating, a lack of exercise, and unbalanced diets $[1,2]$. More than 2.1 billion people (30\% of the global population) are overweight or obese, and approximately half of the world's adult population will be overweight or obese by 2030 if the current growth trend continues [3]. Obesity is closely associated with the development of several diseases, including diabetes, hypertension, dyslipidemia, nonalcoholic steatohepatitis, coronary heart disease, and stroke [4-6]. According to previous reports, obesity is responsible for approximately $5 \%$ of deaths worldwide [3]. The high burden of obesity-related diseases has driven the search for novel and improved strategies to counter obesity $[7,8]$.

Current approaches for treating obesity include lifestyle changes, diet control, regular exercise, surgery and pharmacotherapy as an adjunct treatment. Unfortunately, anti-obesity drugs have consistently exhibited poor efficacy in the management of the patients with obesity, and numerous anti-obesity drugs have been withdrawn from the market based on US FDA warnings of serious side effects and the potential for drug abuse [9-11]. Therefore, interest in the identification of natural remedies to prevent and control obesity with few or no adverse reactions has grown. Recent studies have indicated that some diets and natural compounds, such as the Mediterranean diet and capsaicin, show counteractive effects on obesity $[12,13]$. Cinnamaldehyde (CA), a pungent component of cinnamon (bark of Cinnamomum cassia), is widely used in drugs, food and spices. CA has achieved "Generally Regarded As Safe" status from the FDA. CA has been demonstrated to exhibit a wide range of pharmacological activities, including anti-bacterial, anti-inflammatory, and anti-tumor activities [14-16]. In a previous study, CA was shown to reduce fasting blood glucose and plasma lipid levels [17]. However, few reports have documented an anti-obesity effect of CA. Adipose tissues are important targets for anti-obesity drugs, and adipocyte differentiation is a pivotal process related to the development of obesity. Hence, the present study was designed to investigate the inhibitory effect of CA on body weight gain and the associated mechanisms by which it induces adipose tissue browning in obese mice fed a high-fat diet (HFD).

\section{Materials and Methods}

\section{Reagents and antibodies}

CA was purchased from Sigma-Aldrich (St. Louis, MO, USA). Pioglitazone hydrochloride was purchased from Jiangsu Hengrui Medicine (Jiangsu, China). Antibodies against GAPDH, peroxisome proliferatoractivated receptor $\gamma$ (PPAR $\gamma$ ), PPAR $\gamma$ coactivator $1 \alpha$ (PGC-1 $\alpha)$, and uncoupling protein 1 (UCP1) were purchased from Abcam (Cat \#: ab 8245, ab 209350, ab 54481, ab 10983, Cambridge, MA, USA). Antibodies against PR domain-containing 16 (PRDM16) were purchased from Santa Cruz Biotechnology (Cat \#: sc55697). All other reagents, except where specifically identified, were obtained from Beijing Sinopharm Chemical group (Beijing, China).

\section{Animals and experimental design}

Forty male C57BL/6J mice were maintained under controlled temperature $\left(23 \pm 2{ }^{\circ} \mathrm{C}\right)$ and humidity (55 $\pm 10 \%$ ) conditions with a 12/12-h dark/light cycle. All animals had free access to food and water. At baseline, ten mice were fed a standard diet (10\% kcal as fat, set as the normal control group), and the remaining 30 mice were fed an HFD (60\% kcal as fat) for 12 weeks to promote obesity. The obesity model was considered successfully generated when the body weight of the mice had increased over that of the normal control group by more than 20\%. All diets were manufactured by Mediscience Ltd. (Jingsu, China). Twenty-four obese mice in the HFD group were subsequently selected and randomly subdivided into three groups of eight mice each. The groups were administered pioglitazone ( $5 \mathrm{mg} / \mathrm{kg} / \mathrm{d}), \mathrm{CA}$ ( $40 \mathrm{mg} / \mathrm{kg} \mathrm{BW}$ ) or vehicle (using an equal volume of saline, set as the HFD model group) via gavage daily for 8 weeks. 


\section{Cellular Physiology Cell Physiol Biochem 2017;42:1514-1525

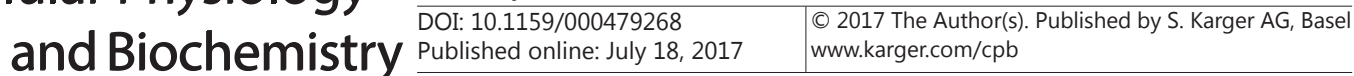 \\ Zuo et al.: Cinnamaldehyde Ameliorates Obesity}

During the experiment, food intake and body weight were monitored weekly. At the end of the study, the mice were anesthetized with pentobarbital sodium and sacrificed after overnight starvation. Blood samples were harvested from the abdominal vena cava, then incubated for $15 \mathrm{~min}$ at room temperature and centrifuged at 3,000 rpm for $15 \mathrm{~min}$. The collected serum was stored until further analysis. Interscapular brown adipose tissue (iBAT) and epididymal white adipose tissue (eWAT) were removed and dissected. The samples were immediately frozen in liquid nitrogen and stored at $-80{ }^{\circ} \mathrm{C}$ for subsequent analysis.

All procedures followed the conventional guidelines for the Care and Use of Laboratory Animals from the Committee for Animal Experiments of the National Center, and the experimental protocol was approved by the Animal Ethics Committee of Beijing University of Chinese Medicine.

\section{Body composition assessment}

The body composition of the mice was assessed via magnetic resonance imaging (EchoMRI-100 for mice, Echo Medical System, Houston, USA) every 4 weeks during the drug administration period (week 4 and 8). Total fat mass was measured, and the fat content was calculated (fat mass weight/body weight $\times 100 \%$ ).

Oral glucose tolerance test

An oral glucose tolerance test (OGTT) was conducted at weeks 4 and 8. Animals were fasted overnight, and the oral glucose load was then administered at a dose of $2 \mathrm{~g} / \mathrm{kg}$ body weight. Glucose levels were measured in blood collected from the tail vein at $0,30,60$, and $120 \mathrm{~min}$ after glucose administration. Glucose tolerance was evaluated by calculating the area under the curve (AUC).

\section{Blood lipid analysis}

Serum total cholesterol (TC), triglyceride (TG), low-density lipoprotein cholesterol (LDL-C) and high-density lipoprotein cholesterol (HDL-C) concentrations were determined using chemical reagent kits (Nanjing Jiancheng Biology Engineering Institute; Nanjing, China) and an automated biochemical analyzer (Hitachi, Tokyo, Japan).

\section{Measurements of free fatty acid and leptin levels}

Plasma free fatty acid (FFA) and leptin levels were measured using ELISA kits (Clinimate NEFA, Tokyo, Japan and R\&D Systems, USA) according to the manufacturer's guidelines.

\section{Histological examination}

At the end of the treatments, the iBAT and eWAT of each mouse were meticulously removed and stored for histological examination. Samples of the adipose tissues were preserved in a freshly prepared fixative solution for $48 \mathrm{~h}$ and then subjected to standard histological procedures, including paraffin embedding, sectioning at a $5 \mu \mathrm{m}$ thickness and staining with hematoxylin and eosin (HE). Images were obtained using a light microscope. For the quantitative analysis of adipocytes, sections of eWAT were analyzed with an image analysis system.

\section{Western blotting}

All adipose tissues were harvested and lysed in RIPA buffer supplemented with a complete protease inhibitor cocktail, and the protein concentration was determined using a BCA Protein Assay kit. Then, 100 $\mu \mathrm{g}$ of each denatured protein sample was separated on a 10\% SDS-PAGE gel and transferred to a PVDF membrane. After blocking with $5 \%$ non-fat milk for $1.5 \mathrm{~h}$ at room temperature, the membranes were incubated with the appropriate primary antibodies overnight at $4{ }^{\circ} \mathrm{C}$, followed by incubation with the corresponding HRP-labeled secondary antibody $(1: 5,000)$ for $1.5 \mathrm{~h}$ at room temperature on the second day. The resultant immune complexes were detected using an enhanced chemiluminescence kit. Protein bands were visualized via autoradiography, and intensities were analyzed using Quantity One (Bio-Rad Laboratories, Hercules, CA, USA). GAPDH was used as the loading control.

\section{Statistical analysis}

All values are presented as the mean \pm standard errors of the mean (SEM). One-way ANOVA and subsequent Dunnett's multiple comparisons tests were conducted using GraphPad software (Prism 5.0, Inc., CA, USA). When data were compared between groups, $\mathrm{P}<0.05$ was considered significant. 


\section{Results}

CA reduced body weight and food intake in HFD-fed mice

Compared with mice fed a standard diet, mice fed an HFD exhibited an obvious increase in body weight. Both pioglitazone and CA decreased body weight beginning at 6 weeks (Fig. 1A). At the end of the experiment, the mice fed an HFD gained more weight than the mice fed a standard diet, and both CA and pioglitazone administration tended to decrease HFDinduced body weight gain. However, compared with the mice in the HFD control group, only the CA-treated group exhibited a significant difference (Fig. 1B).

Furthermore, food intake was concomitantly reduced in the CA-treated group mice (Fig. 1C). Food intake was not significantly different between the HFD-fed mice with or without CA supplementation until the fifth week. The mice fed an HFD consumed more calories than the mice fed a standard diet. The results indicate that CA supplementation triggered a negative energy balance by suppressing energy intake.

\section{CA altered the body composition of HFD-fed mice}

In the fourth week, the fat mass of the mice fed an HFD had increased by approximately twofold compared with the normal control group. The CA and pioglitazone treatments tended to decrease the fat mass of the mice, but the difference was not significant compared with the HFD group (Fig. 1D).

At the end of the experiment, the fat mass of the mice fed an HFD was increased approximately threefold compared with the normal control group, whereas CA administration obviously reversed this trend, as demonstrated by a $32.1 \%$ decrease in fat mass relative to the HFD control group. Again, the fat mass of the mice fed an HFD and treated with pioglitazone was significantly reduced (approximately 36.0\%) compared with the HFD control group

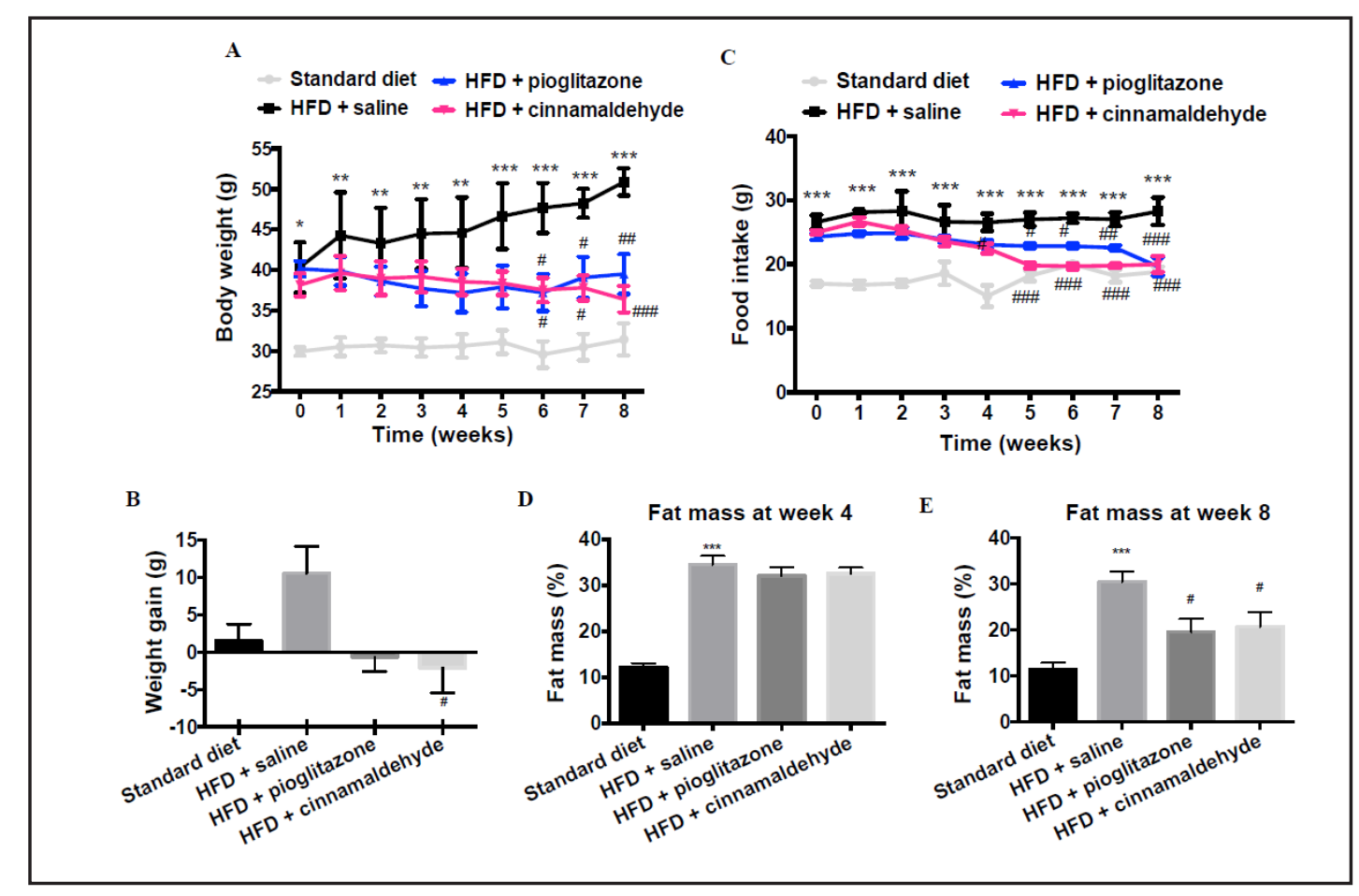

Fig. 1. Cinnamaldehyde reduced body weight, food intake and fat mass of the HFD-exposed mice. (A) Body weight changes in the mice. (B) Body weight gains were decreased by cinnamaldehyde. (C) Daily food intake of the mice. (D) Differences in fat masses/body weights between groups at week 4. (E) Cinnamaldehyde reduced fat masses/body weights at the end of the experiment. Data are expressed as the mean \pm SEM of eight mice from each group. ${ }^{*} \mathrm{P}<0.05,{ }^{* *} \mathrm{P}<0.01$ vs. normal control group. ${ }^{*} \mathrm{P}<0.05$, ${ }^{\# \#} \mathrm{P}<0.01$ vs. HFD control group. 
(Fig. 1E). The results suggest that CA-treated mice gained more lean body mass than fat body mass.

\section{Effect of CA on OGTT in HFD-fed mice}

As shown in the OGTT results presented in Fig. 2, no significant differences in glucose levels or the AUC were observed among the groups at week 4 (Fig. 2A and B). However, at the end of the treatment period, the glucose levels of the mice fed an HFD were significantly increased at 30, 60 and 120 min after oral glucose administration compared with the mice fed a standard diet. The increase in blood glucose levels in the HFD model group was significantly reduced by CA and pioglitazone treatments (Fig. 2C). In addition, HFD induced a significant increase in the AUC, which was decreased by CA and pioglitazone treatments (Fig. 2D). Therefore, CA administration alleviated insulin resistance in obese mice in a timedependent manner.

\section{Effect of CA on the blood lipid profile in HFD-fed mice}

Serum TC, TG and LDL-C levels were significantly increased in the mice fed an HFD compared with the mice fed a standard diet. CA treatment significantly suppressed the increases in serum TC, TG and LDL-C levels by $24.9 \%, 57.0 \%$, and $50.9 \%$, respectively (Fig. $3 \mathrm{~A}-\mathrm{C})$. The serum HDL-C levels of the CA-treated group were increased by $44.9 \%$ compared with the HFD model group (Fig. 3D). The obtained results suggest that CA treatment beneficially modulates the blood lipid profile.

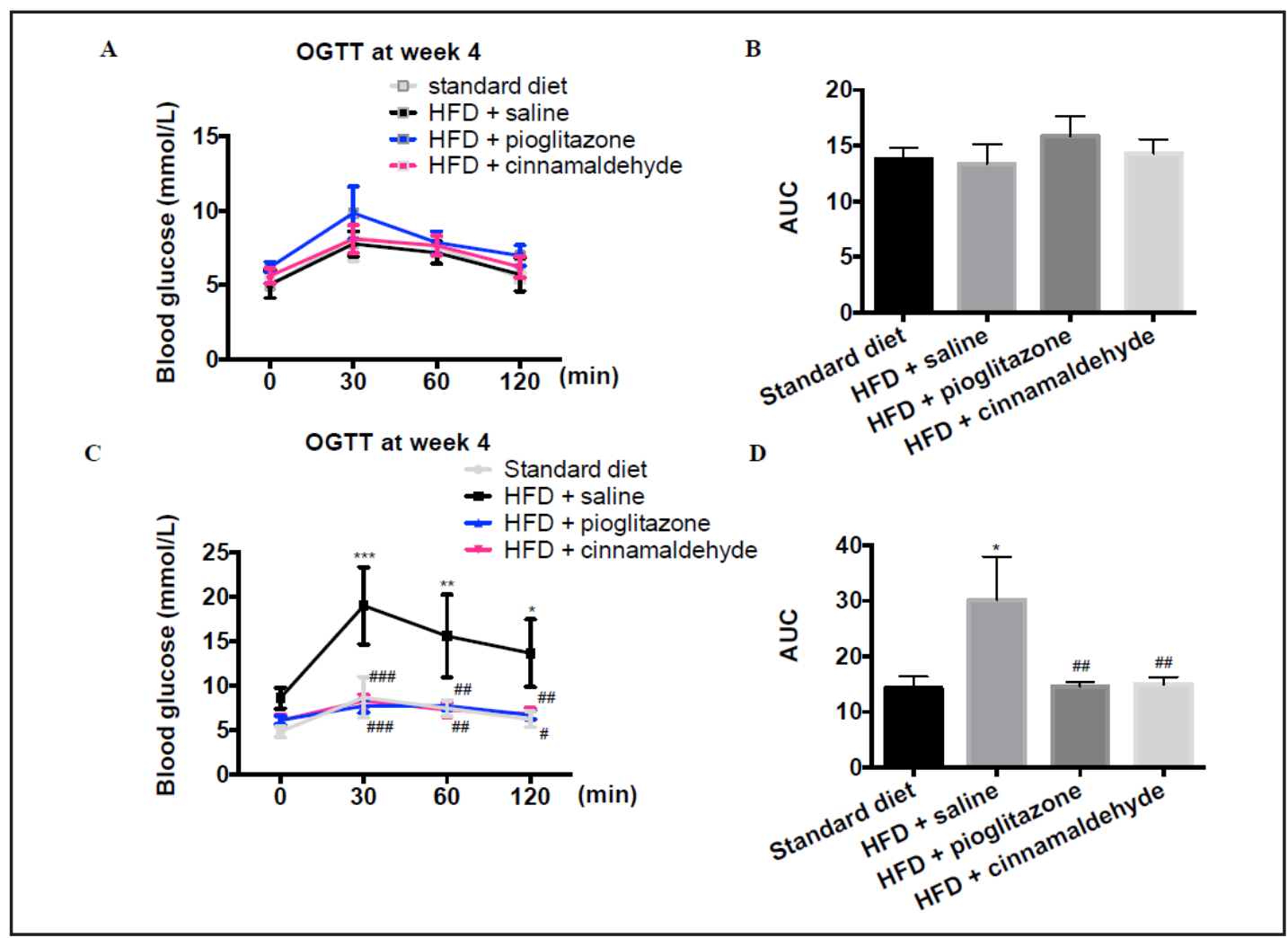

Fig. 2. Cinnamaldehyde improved OGTT in HFD-exposed mice. (A) and (C) show the results of OGTT for each group at the fourth and eighth weeks. (B) and (D) show comparisons of the areas under the OGTT curves (AUCs) among groups at the fourth and eighth weeks. Data are expressed as the mean \pm SEM of eight mice from each group. ${ }^{*} \mathrm{P}<0.05,{ }^{* *} \mathrm{P}<0.01$ vs. normal control group. $\# \mathrm{P}<0.05$, $\# \# \mathrm{P}<0.01$ vs. HFD control group. 


\section{CA decreased serum FFA and leptin contents in HFD-fed mice}

As shown in Fig. 3E, FFA and leptin levels were higher in the mice fed an HFD than in mice fed a standard diet. In addition, serum FFA levels were significantly reduced by CA and pioglitazone treatments ( $10.1 \%$ and $10.4 \%$, respectively). Similarly, serum leptin levels were decreased by approximately $28.7 \%$ and $42.6 \%$ in mice fed an HFD that were treated with CA and pioglitazone, respectively, compared with the HFD control group (Fig. 3F).

\section{Effect of CA on adipose tissue morphology in HFD-fed mice}

As shown by the HE staining results presented in Fig. 4, the morphology of iBAT and eWAT in the mice was altered by the HFD. However, CA and pioglitazone supplementation attenuated these changes. Specifically, in iBAT, multilocular brown adipocytes with larger lipid droplets were observed in the HFD model group, indicating more intense lipid metabolism. However, HFD-fed mice treated with CA and pioglitazone exhibited few lipid droplets within multilocular brown adipocytes, implying high metabolic activity (Fig. 4A and $4 \mathrm{~B})$. The sizes and numbers of adipocytes in eWAT were quantified in a fixed area $(600,000 \mathrm{um} 2)$. The results demonstrated that the HFD-induced adipocyte hypertrophy and hyperplasia in eWAT. Furthermore, the administration of CA or pioglitazone prevented adipocyte hypertrophy and hyperplasia in HFD-fed mice, as demonstrated by a decrease in the average adipocyte diameter (Fig. 4C and 4D). The results suggest that CA administration

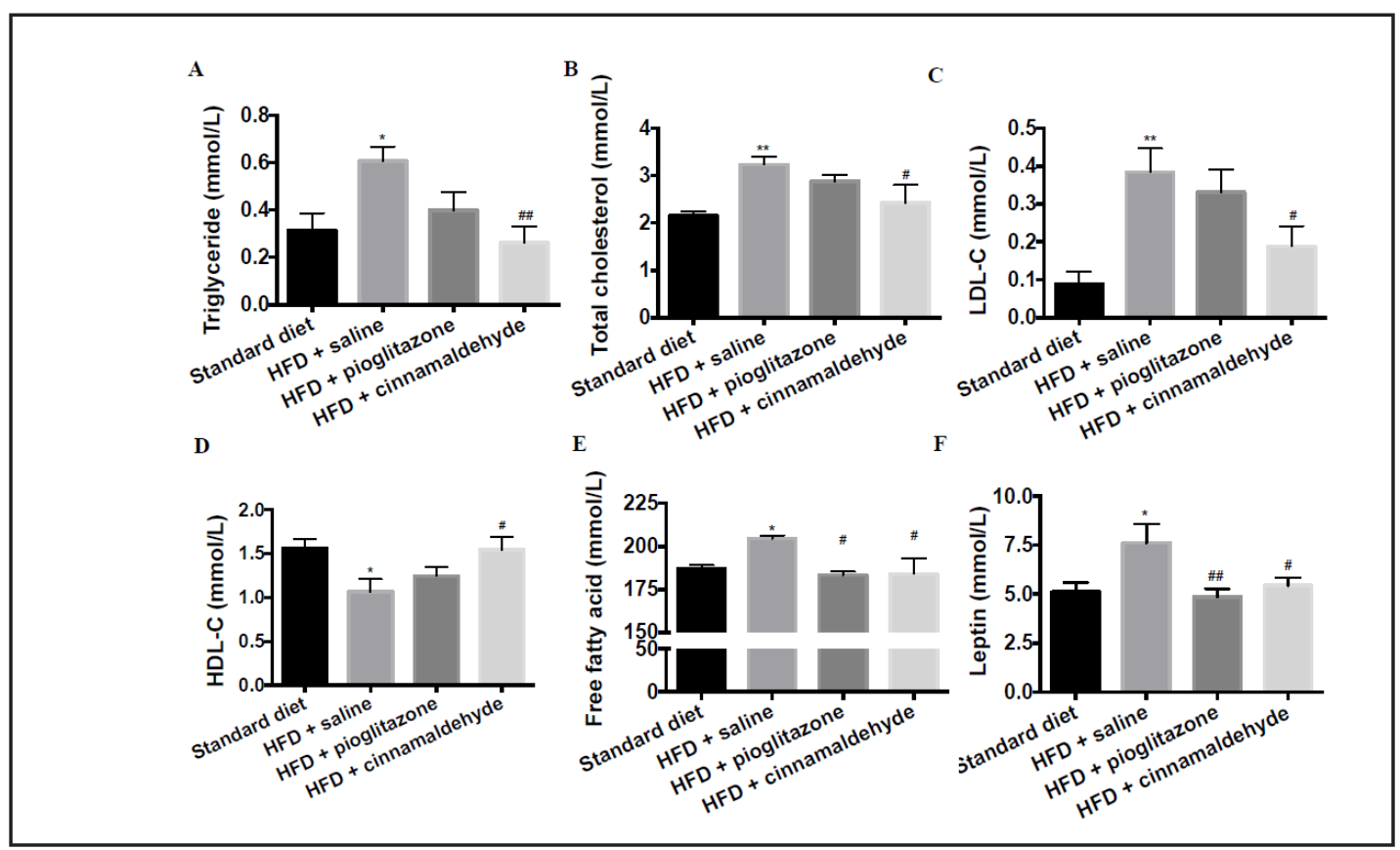

Fig. 3. Cinnamaldehyde decreased blood lipid profile and FFA and leptin levels in HFD exposed mice. (A) TG, triglyceride; (B) TC, total cholesterol; (C) LDL-C, low-density lipoprotein cholesterol; (D) HDL-C, highden-sity lipoprotein cholesterol; (E) FFA, free fatty acid; (F) Leptin. Values are expressed as the mean \pm SEM of eight mice from each group. ${ }^{*} \mathrm{P}<0.05$, ${ }^{* *} \mathrm{P}<0.01$ vs. normal control group. $\# \mathrm{P}<0.05, \# \# \mathrm{P}<0.01$ vs. HFD control group.

attenuates HFD-induced adipocyte hypertrophy and hyperplasia in eWAT and promote metabolic activity in iBAT in mice.

CA regulates the expression of the UCP1, PPAR $\gamma, P G C-1 \alpha$ and PRDM16 proteins in iBAT and eWAT in HFD-fed mice

As expected, the PPAR $\gamma$ and PRDM16 proteins were down-regulated in iBAT from HFDfed mice compared with their expression in iBAT from animals fed a standard diet. CA and 
pioglitazone supplementation increased the levels of the PPAR $\gamma$ protein compared with the HFD-fed group. In addition to the agonistic effects on PPAR $\gamma$, the expression of its target proteins PRDM16 and PGC-1 $\alpha$ was also significantly increased. However, we did not observe any changes in UCP1 protein expression in iBAT between the groups (Fig. 5A).

The UCP1 protein was not detected in eWAT from mice fed a standard diet or the HFD control group. However, both CA and pioglitazone induced UCP1 protein expression, suggesting that these treatments induced the appearance of brown-like adipocytes in eWAT. In addition, the CA treatment induced a significant increase in the relative expression levels

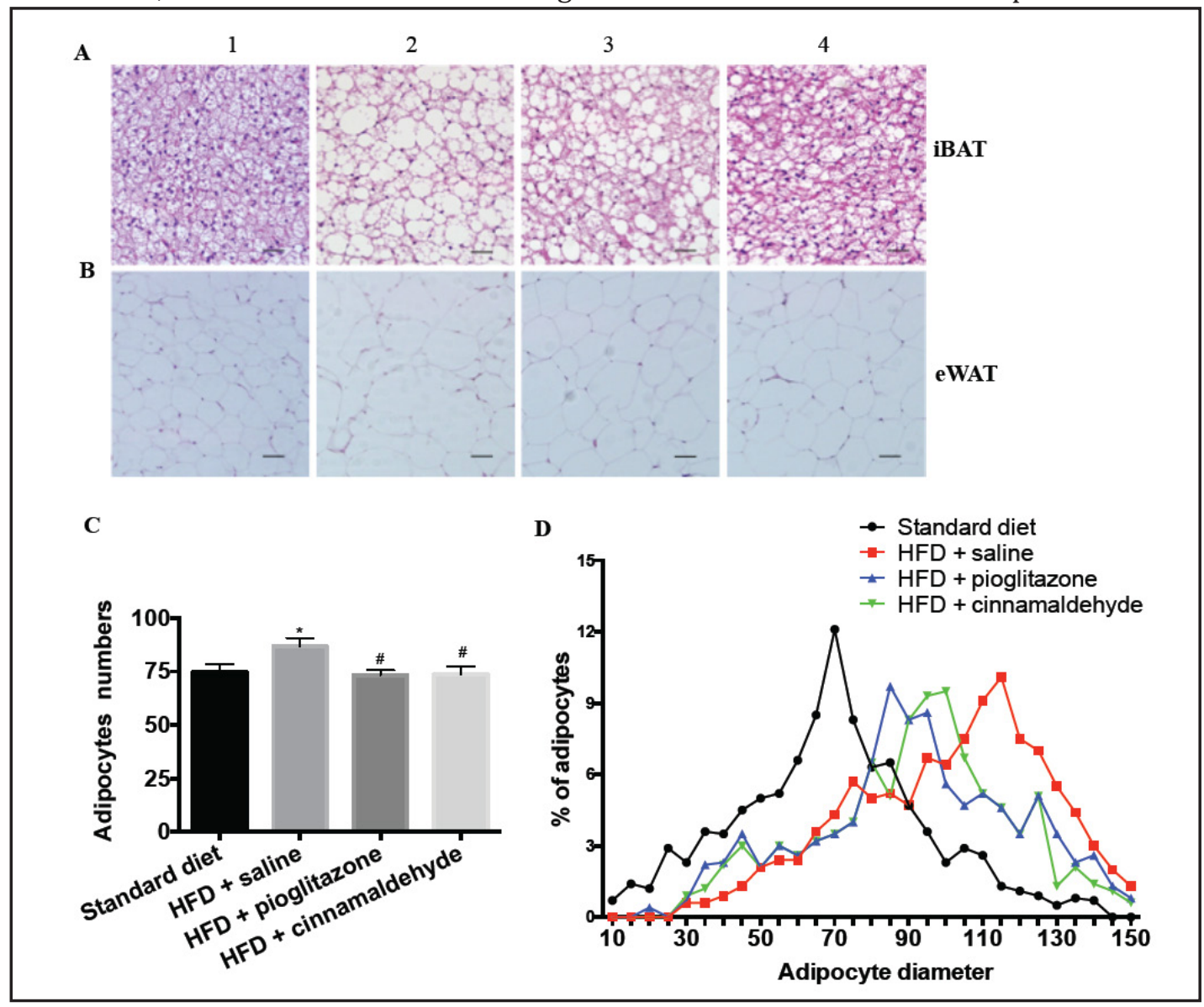

Fig. 4. Cinnamaldehyde altered the morphology of adipose tissues. (A) and (B) are representative images $(200 \times)$ of HE-stained sections of adipose tissues from the iBAT and eWAT of the mice in the normal control group (1), HFD control group (2), pioglitazone treatment group (3) and cinnamaldehyde treatment group (4). Scale bars $=50 \mu \mathrm{m}$. (C) Numbers of adipocytes and (D) percent of adipocyte diameters in the fixed area $\left(600,000 \mathrm{~m}^{2}\right)$ in eWAT.

of the PGC-1 $\alpha$, PPAR $\gamma$ and PRDM16 proteins compared with the saline-treated mice fed an HFD (Fig. 5B).

\section{Discussion}

Emerging evidence supports the notion that natural products can play a positive role in the management of obesity $[18,19]$. Cinnamon, which is used as an herbal drug and spice, has been employed to treat obesity and diabetes for thousands of years in traditional Chinese medicine [20]. CA, the main volatile oil constituent of cinnamon, exhibits glucoselowering activity [21]. Furthermore, CA positively alters body composition in vivo [22, 23] 
$\mathbf{A}$

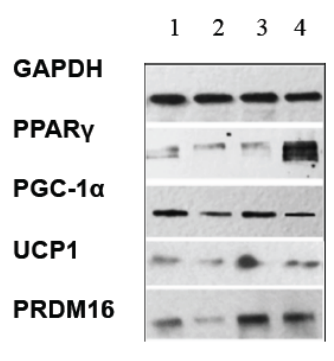

B

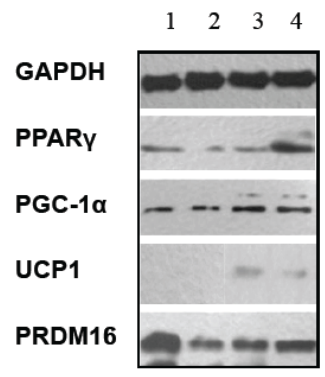

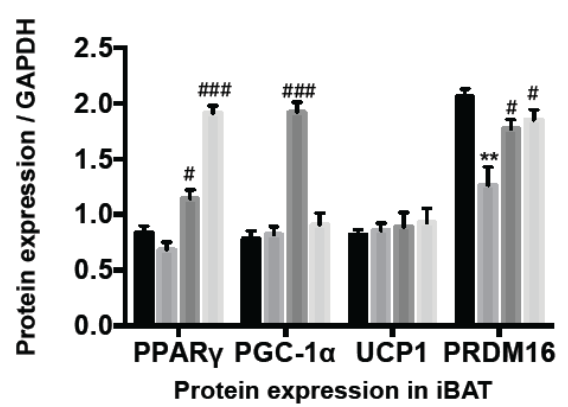

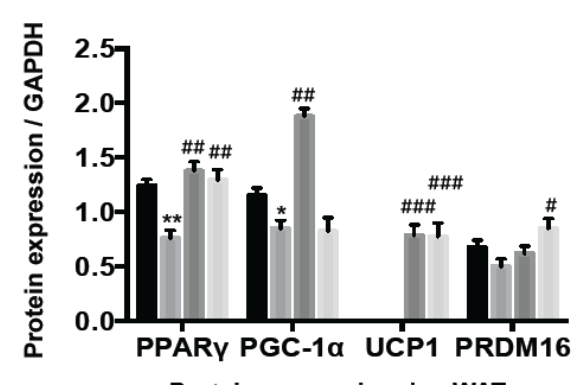

Protein expression in eWAT

Fig. 5. Cinnamaldehyde regulates expression of the relevant proteins. The representative western blotting results demonstrated that cinnamaldehyde treatment attenuated HFD-induced obesity through regulation of the expressions of PPAR $\gamma$, PGC- $1 \alpha$, UCP1, and PRDM16 in iBAT and eWAT in mice. (1), normal control group; (2), HFD control group; (3), pioglitazone treatment group; (4), cinnamaldehyde treatment group. $\operatorname{PPAR} \gamma$, peroxisome proliferator-activated receptor $\gamma$; PGC- $1 \alpha$, PPAR $\gamma$ coactivator $1 \alpha$; UCP1, uncoupling protein 1; PRDM16, PR domain-containing 16. Values are expressed as the mean \pm SE of three mice from each group. ${ }^{*} \mathrm{P}<0.05$ vs. normal control group. $\# \mathrm{P}<0.05$ vs. HFD control group.

and regulates adipocyte differentiation in vitro [24]. Consistent with previous studies [14, 25], our results demonstrated that CA significantly suppressed body weight gain, food intake and fat accumulation in HFD-induced obese mice. Furthermore, eight weeks of CA administration reduced the blood lipid profile and FFA and leptin levels. As reported in previous studies, leptin resistance may be one of the major causes of obesity [26]. The effect of CA in decreasing leptin contents may be responsible for body weight loss. In addition, elevated FFA levels are important for insulin resistance in obesity [27]. In the present study, insulin resistance in the obese mice was relieved by CA treatment, suggesting that CA potentially improves insulin sensitivity by regulating FFA levels.

Obesity arises from an imbalance between energy intake and expenditure. Obesity is closely related to the hypertrophy and hyperplasia of white adipocytes. Two major types of adipose tissue exist in mammals: WAT and BAT. WAT generally accounts for as much as $20 \%$ of the body weight of normal adult humans and primarily acts as a storage site for triglycerides, conserving excess calories for use in times of scarcity. Conversely, BAT is specialized to dissipate chemical energy as heat $[28,29]$. The unique ability of BAT makes it a metabolically beneficial phenotype for obesity and obesity-related diseases [30]. Due to the similarity of the structures of the two adipose tissue types, they can mutually transdifferentiate into the other type. Based on accumulating evidence, morphological transition from the WAT phenotype to the BAT phenotype, a process known as "browning", may facilitate the treatment of obesity [31]. The conversion of WAT to BAT is initiated by various conditions and agents, such as cold exposure [32] and the PPAR agonist rosiglitazone [33, 34]. Hence, pioglitazone was chosen as a positive control drug. The activation and/or expansion of BAT reduces body weight and increases insulin sensitivity. In the present study, CA attenuated HFD-induced adipocyte hypertrophy and hyperplasia in eWAT and iBAT and increased the number of multilocular brown adipocytes in eWAT, triggering the browning of eWAT [35]. 


\section{Cellular Physiology Cell Physiol Biochem 2017;42:1514-1525

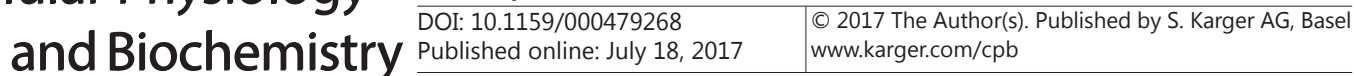 \\ Zuo et al.: Cinnamaldehyde Ameliorates Obesity}

Then, we further measured the expression of relevant proteins to investigate the molecular mechanisms correlated with the morphological changes occurring in adipose tissues.

The "beige" fat cells generated from the browning process switch from an energy storage state to an energy dissipation state and express specific molecular markers, such as UCP1 [36, 37]. UCP1, which constitutes the most specific difference in the biochemical characteristics of white adipocytes and brown adipocytes, is an essential molecule for metabolic thermogenesis. UCP1 is only expressed in the mitochondria in brown adipocytes [38]. As expected, the expression of the UCP1 protein was increased in iBAT and emerged in eWAT. Moreover, recent studies have identified several other dominant transcriptional regulators of brown adipocyte development and function, including PPAR $\gamma$, cAMP response element-binding protein (CREB), PGC-1 $\alpha$, and PRDM16 [39, 40]. PPAR $\gamma$ is expressed abundantly and at equal levels in white fat and brown fat and is required for the development of both cell types [41]. However, activation of PPAR $\gamma$ by synthetic ligands induces a brown fat-like gene program in WAT [42]. Increased PPAR $\gamma$ expression in WAT reduces the number of mature, large adipocytes and increases the number of small adipocytes, which improves the metabolism of this tissue [43]. Therefore, PPAR $\gamma$ is recognized as a master regulator of adipogenesis. However, PPAR $\gamma$ activation is not adequate or sufficient for white-to-brown adipocyte transition. Instead, PRDM16, which directly interacts with PPAR $\gamma$ and coactivates the transcriptional activity of PPAR $\gamma$, is also required to activate a thermogenic brown fat gene program [42]. In addition, PGC- $1 \alpha$ is of particular importance, given its roles in upregulating UCP1 expression and the uncoupling of mitochondrial fat combustion from ATP production $[44,45]$. Consistent with these reports, in the present study, we showed that CA supplementation up-regulates the expression of the PPAR $\gamma$, PRDM1 6 and PGC- $1 \alpha$ proteins to promote the conversion of WAT to BAT.

In summary, CA treatment reduced body weight, body fat and blood lipid levels by inducing the browning of WAT and suppressing the whitening of brown adipose tissue in HFD-fed mice. Based on these findings, we concluded that CA is an efficient and safe alternative to anti-obesity agents. Therefore, CA has the potential to play a role in the therapeutic treatment of obesity and related disorders in the future, although the underlying mechanism requires further investigation.

\section{Acknowledgements}

This study was supported by grants from the Key Drug Development Program of MOST (20122X09103201-005), the National Natural Science Foundation of China (81273995, 81274041 and 81503540), the International Cooperation Projects of MOE (2011DFA30920) and Co-construction Project of Beijing Education Commission (0101216-14).

\section{Disclosure Statement}

None.

\section{References}

1 Diniz MF, Beleigoli AM, Ribeiro AL, Vidigal PG, Bensenor IM, Lotufo PA, Duncan BB, Schmidt MI, Barreto SM: Factors associated with metabolically healthy status in obesity, overweight, and normal weight at baseline of ELSA-Brasil. Medicine 2016;95:e4010. 


\section{Cellular Physiology Cell Physiol Biochem 2017;42:1514-1525

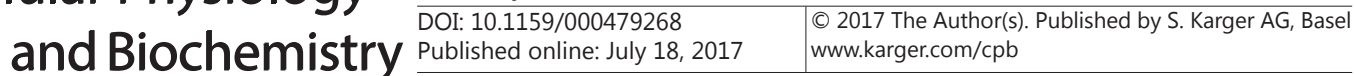 \\ Zuo et al.: Cinnamaldehyde Ameliorates Obesity}

2 Cha E, Akazawa MK, Kim KH, Dawkins CR, Lerner HM, Umpierrez G, Dunbar SB: Lifestyle habits and obesity progression in overweight and obese American young adults: lessons for promoting cardiometabolic health. Nurs Health Sci 2015;17:467-475.

3 Ng M, Fleming T, Robinson M, Thomson B, Graetz N, Margono C, Mullany EC, Biryukov S, Abbafati C, Abera SF, Abraham JP, Abu-Rmeileh NM, Achoki T, AlBuhairan FS, Alemu ZA, Alfonso R, Ali MK, Ali R, Guzman NA, Ammar W, Anwari P, Banerjee A, Barquera S, Basu S, Bennett DA, Bhutta Z, Blore J, Cabral N, Nonato IC, Chang JC, Chowdhury R, Courville KJ, Criqui MH, Cundiff DK, Dabhadkar KC, Dandona L, Davis A, Dayama A, Dharmaratne SD, Ding EL, Durrani AM, Esteghamati A, Farzadfar F, Fay DF, Feigin VL, Flaxman A, Forouzanfar MH, Goto A, Green MA, Gupta R, Hafezi-Nejad N, Hankey GJ, Harewood HC, Havmoeller R, Hay S, Hernandez L, Husseini A, Idrisov BT, Ikeda N, Islami F, Jahangir E, Jassal SK, Jee SH, Jeffreys M, Jonas JB, Kabagambe EK, Khalifa SE, Kengne AP, Khader YS, Khang YH, Kim D, Kimokoti RW, Kinge JM, Kokubo Y, Kosen S, Kwan G, Lai T, Leinsalu M, Li Y, Liang X, Liu S, Logroscino G, Lotufo PA, Lu Y, Ma J, Mainoo NK, Mensah GA, Merriman TR, Mokdad AH, Moschandreas J, Naghavi M, Naheed A, Nand D, Narayan KM, Nelson EL, Neuhouser ML, Nisar MI, Ohkubo T, Oti SO, Pedroza A, Prabhakaran D, Roy N, Sampson U, Seo H, Sepanlou SG, Shibuya K, Shiri R, Shiue I, Singh GM, Singh JA, Skirbekk V, Stapelberg NJ, Sturua L, Sykes BL, Tobias M, Tran BX, Trasande L, Toyoshima H, van de Vijver S, Vasankari TJ, Veerman JL, VelasquezMelendez G, Vlassov VV, Vollset SE, Vos T, Wang C, Wang X, Weiderpass E, Werdecker A, Wright JL, Yang YC, Yatsuya H, Yoon J, Yoon SJ, Zhao Y, Zhou M, Zhu S, Lopez AD, Murray CJ, Gakidou E: Global, regional, and national prevalence of overweight and obesity in children and adults during 1980-2013: a systematic analysis for the Global Burden of Disease Study 2013. Lancet 2014;384:766-781.

4 Hu J, Yang S, Zhang A, Yang P, Cao X, Li X, Goswami R, Wang Y, Luo T, Liao K, Cheng Q, Xiao X, Li Q: Abdominal obesity is more closely associated with diabetic kidney disease than general obesity. Diabetes Care 2016;39:e179-180.

-5 Vinciguerra F, Baratta R, Farina MG, Tita P, Padova G, Vigneri R, Frittitta L: Very severely obese patients have a high prevalence of type 2 diabetes mellitus and cardiovascular disease. Acta Diabetol 2013;50:443449.

6 Matsuda M, Shimomura I: Increased oxidative stress in obesity: implications for metabolic syndrome, diabetes, hypertension, dyslipidemia, atherosclerosis, and cancer. Obes Res Clin Pract 2013;7:e330-e341.

7 Withrow D, Alter DA: The economic burden of obesity worldwide: a systematic review of the direct costs of obesity. Obes Rev 2011;12:131-141.

8 Cai L, Lubitz J, Flegal KM, Pamuk ER: The predicted effects of chronic obesity in middle age on medicare costs and mortality. Med Care 2010;48:510-517.

-9 Yanovski SZ, Yanovski JA: Long-term drug treatment for obesity: a systematic and clinical review. JAMA 2014;311:74-86.

10 Xia Y, Kelton CM, Guo JJ, Bian B, Heaton PC: Treatment of obesity: pharmacotherapy trends in the United States from 1999 to 2010. Obesity 2015;23:1721-1728.

-11 Karupiah S, Ismail Z: Anti-obesity effects of melastoma malabathricum var alba linn in rats fed with a highfat diet. AAPS PharmSciTech 2015;16:548-553.

12 Trigueros L, Pena S, Ugidos AV, Sayas-Barbera E, Perez-Alvarez JA, Sendra E: Food ingredients as antiobesity agents: a review. Crit Rev Food Sci Nutr 2013;53:929-942.

13 Gomez-Arbelaez D, Bellido D, Castro AI, Ordonez-Mayan L, Carreira J, Galban C, Martinez-Olmos MA, Crujeiras AB, Sajoux I, Casanueva FF: Body composition changes after very low-calorie-ketogenic diet in obesity evaluated by three standardized methods. J Clin Endocrinol Metab 2016;102:488-498.

14 Sartorius T, Peter A, Schulz N, Drescher A, Bergheim I, Machann J, Schick F, Siegel-Axel D, Schurmann A, Weigert C, Haring HU, Hennige AM: Cinnamon extract improves insulin sensitivity in the brain and lowers liver fat in mouse models of obesity. PLoS One 2014;9:e92358.

15 Kim BH, Lee YG, Lee J, Lee JY, Cho JY: Regulatory effect of cinnamaldehyde on monocyte/macrophagemediated inflammatory responses. Mediators Inflamm 2010;2010:529359.

16 Yun M, Lee D, Park MN, Kim EO, Sohn EJ, Kwon BM, Kim SH: Cinnamaldehyde derivative (CB-PIC) sensitizes chemo-resistant cancer cells to drug-induced apoptosis via suppression of MDR1 and its upstream STAT3 and AKT signalling. Cell Physiol Biochem 2015;35:1821-1830.

17 Kannappan S, Jayaraman T, Rajasekar P, Ravichandran MK, Anuradha CV: Cinnamon bark extract improves glucose metabolism and lipid profile in the fructose-fed rat. Singapore Med J 2006;47:858-863. 


\section{Cellular Physiology Cell Physiol Biochem 2017;42:1514-1525 \begin{tabular}{l|l} 
DOI: 10.1159/000479268 & $\begin{array}{l}\text { O 2017 The Author(s). Published by S. Karger AG, Basel } \\
\text { www.karger.com/cpb }\end{array}$
\end{tabular} \\ Zuo et al.: Cinnamaldehyde Ameliorates Obesity}

18 Gamboa-Gomez CI, Rocha-Guzman NE, Gallegos-Infante JA, Moreno-Jimenez MR, Vazquez-Cabral BD, Gonzalez-Laredo RF: Plants with potential use on obesity and its complications. EXCLI J 2015;14:809-831.

-19 Wang S, Wang X, Ye Z, Xu C, Zhang M, Ruan B, Wei M, Jiang Y, Zhang Y, Wang L, Lei X, Lu Z: Curcumin promotes browning of white adipose tissue in a norepinephrine-dependent way. Biochem Biophys Res Commun 2015;466:247-253.

20 Khan A, Safdar M, Ali KMM, Khattak KN, Anderson RA: Cinnamon improves glucose and lipids of people with type 2 diabetes. Diabetes Care 2003;26:3215-3218.

21 Wang F, Pu C, Zhou P, Wang P, Liang D, Wang Q Hu Y, Li B, Hao X: Cinnamaldehyde prevents endothelial dysfunction induced by high glucose by activating Nrf2. Cell Physiol Biochem 2015;36:315-324.

-22 Lu T, Sheng H, Wu J, Cheng Y, Zhu J, Chen Y: Cinnamon extract improves fasting blood glucose and glycosylated hemoglobin level in Chinese patients with type 2 diabetes. Nutr Res 2012;32:408-412.

23 Khare P, Jagtap S, Jain Y, Baboota RK, Mangal P, Boparai RK, Bhutani KK, Sharma SS, Premkumar LS, Kondepudi KK, Chopra K, Bishnoi M: Cinnamaldehyde supplementation prevents fasting-induced hyperphagia, lipid accumulation, and inflammation in high-fat diet-fed mice. Biofactors 2016;42:201-211.

-24 Huang B, Yuan HD, Kim DY, Quan HY, Chung SH: Cinnamaldehyde prevents adipocyte differentiation and adipogenesis via regulation of peroxisome proliferator-activated receptor-gamma (PPARgamma) and AMPactivated protein kinase (AMPK) pathways. J Agric Food Chem 2011;59:3666-3673.

25 Mang B, Wolters M, Schmitt B, Kelb K, Lichtinghagen R, Stichtenoth DO, Hahn A: Effects of a cinnamon extract on plasma glucose, $\mathrm{HbA}$, and serum lipids in diabetes mellitus type 2. Eur J Clin Invest 2006;36:340344.

26 Park BG, Park YS, Park JW, Shin E, Shin WS: Anti-obesity potential of enzymatic fragments of hyaluronan on high-fat diet-induced obesity in C57BL/6 mice. Biochem Biophys Res Commun 2016;473:290-295.

27 Arner P, Ryden M: Fatty acids, obesity and insulin resistance. Obes Facts 2015;8:147-155.

28 Lidell ME, Betz MJ, Enerback S: Two types of brown adipose tissue in humans. Adipocyte 2014;3:63-66.

-29 Bartelt A, Bruns OT, Reimer R, Hohenberg H, Ittrich H, Peldschus K, Kaul MG, Tromsdorf UI, Weller H, Waurisch C, Eychmuller A, Gordts PL, Rinninger F, Bruegelmann K, Freund B, Nielsen P, Merkel M, Heeren J: Brown adipose tissue activity controls triglyceride clearance. Nat Med 2011;17:200-205.

-30 Kajimura S: Engineering fat cell fate to fight obesity and metabolic diseases. Keio J Med 2015;64:65.

-31 Contreras C, Gonzalez-Garcia I, Seoane-Collazo P, Martinez-Sanchez N, Linares-Pose L, Rial-Pensado E, Ferno J, Tena-Sempere M, Casals N, Dieguez C, Nogueiras R, Lopez M: Reduction of hypothalamic ER stress activates browning of white fat and ameliorates obesity. Diabetes 2016;66:87-99.

32 Jankovic A, Golic I, Markelic M, Stancic A, Otasevic V, Buzadzic B, Korac A, Korac B: Two key temporally distinguishable molecular and cellular components of white adipose tissue browning during cold acclimation. J Physiol 2015;593:3267-3280.

-33 Petrovic N, Walden TB, Shabalina IG, Timmons JA, Cannon B, Nedergaard J: Chronic peroxisome proliferator-activated receptor gamma (PPARgamma) activation of epididymally derived white adipocyte cultures reveals a population of thermogenically competent, UCP1-containing adipocytes molecularly distinct from classic brown adipocytes. J Biol Chem 2010;285:7153-7164.

-34 Vernochet C, Peres SB, Davis KE, McDonald ME, Qiang L, Wang H, Scherer PE, Farmer SR: C/EBPalpha and the corepressors $\mathrm{CtBP} 1$ and $\mathrm{CtBP} 2$ regulate repression of select visceral white adipose genes during induction of the brown phenotype in white adipocytes by peroxisome proliferator-activated receptor gamma agonists. Mol Cell Biol 2009;29:4714-4728.

-35 Cedikova M, Kripnerova M, Dvorakova J, Pitule P, Grundmanova M, Babuska V, Mullerova D, Kuncova J: Mitochondria in white, brown, and beige adipocytes. Stem Cells Int 2016;2016:6067349.

-36 Castrejon-Tellez V, Rodriguez-Perez JM, Perez-Torres I, Perez-Hernandez N, Cruz-Lagunas A, Guarner-Lans V, Vargas-Alarcon G, Rubio-Ruiz ME: The effect of resveratrol and quercetin treatment on PPAR mediated uncoupling protein (UCP-) 1, 2, and 3 expression in visceral white adipose tissue from metabolic syndrome rats. Int J Mol Sci 2016;17:1069.

-37 Kajimura S, Seale P, Spiegelman BM: Transcriptional control of brown fat development. Cell Metab 2010;11:257-262.

-38 Dempersmier J, Sambeat A, Gulyaeva O, Paul SM, Hudak CS, Raposo HF, Kwan HY, Kang C, Wong RH, Sul HS: Cold-inducible Zfp516 activates UCP1 transcription to promote browning of white fat and development of brown fat. Mol Cell 2015;57:235-246. 


\section{Cellular Physiology Cell Physiol Biochem 2017;42:1514-1525 \begin{tabular}{l|l} 
and Biochemistry 10.1159/000479268 & $\begin{array}{l}\text { O 2017 The Author(s). Published by S. Karger AG, Basel } \\
\text { www.karger.com/cpb }\end{array}$ \\
\cline { 2 - 3 }
\end{tabular} \\ Zuo et al.: Cinnamaldehyde Ameliorates Obesity}

-39 Lizcano F, Vargas D: Biology of beige adipocyte and possible therapy for type 2 diabetes and obesity. Int J Endocrinol 2016;2016:9542061.

40 Seale P: Transcriptional regulatory circuits controlling brown fat development and activation. Diabetes 2015;64:2369-2375.

41 Farmer SR: Transcriptional control of adipocyte formation. Cell Metab 2006;4:263-273.

42 Ohno H, Shinoda K, Spiegelman BM, Kajimura S: PPARgamma agonists induce a white-to-brown fat conversion through stabilization of PRDM16 protein. Cell Metab 2012;15:395-404.

43 Magliano DC, Bargut TC, de Carvalho SN, Aguila MB, Mandarim-de-Lacerda CA, Souza-Mello V: Peroxisome proliferator-activated receptors-alpha and gamma are targets to treat offspring from maternal dietinduced obesity in mice. PLoS One 2013;8:e64258.

44 Kim J, Fernand VE, Henagan TM, Shin J, Huypens P, Newman S, Gettys TW, Chang JS: Regulation of brown and white adipocyte transcriptome by the transcriptional coactivator NT-PGC-1alpha. PLoS One 2016;11:e0159990.

45 Becerril S, Gomez-Ambrosi J, Martin M, Moncada R, Sesma P, Burrell MA, Fruhbeck G: Role of PRDM16 in the activation of brown fat programming. Relevance to the development of obesity. Histol Histopathol 2013;28:1411-1425. 